2013, Vol. 2, Issue 2

\title{
SOVEREIGN BONDS AS INVESTMENTS? A COMMENT ON THE ABACLAT AND AMBIENTE UFFICIO DECISIONS ON JURISDICTION
}

\author{
Michał Pyka*
}

\section{Introduction}

Decisions on jurisdiction and admissibility in Abaclat and others v. the Argentine Republic of 11.8.2011 ("the Abaclat decision") $)^{1}$ and Ambiente Ufficio S.p.A. and others v. the Argentine Republic of 8.2.2013 (the Ambiente Ufficio decision) ${ }^{2}$ have caused considerable controversy ${ }^{3}$

* Ph.D candidate at the Jagiellonian University in Cracow, Faculty of Law and Administration; trainee legal advisor at the Cracow Bar of Legal Advisors.

1 Abaclat and others v. the Argentine Republic, Decision on jurisdiction and admissibility of 11.8.2011, ICSID Case no ARB/07/5.

2 Ambiente Ufficio S.p.A. and others v. the Argentine Republic, Decision on jurisdiction and admissibility of 8.2.2013, ICSID Case no ARB/08/9 (formerly Giordano Alpi and others v. Argentine Republic).

3 The Abaclat decision has been held to be the "most controversial or surprising" Arbitration Decision of the Year 2011 by the members of the Oil-Gas-Energy-MiningInfrastructure Dispute Management (OGEMID), available at: http://www.transnationaldispute-management.com/ogemidawards/. See also: D. Herlihy, D. Kavanagh, Timothy G. Nelson, The Increasing Appeal and Novel Use of Bilateral Investment Treaties, Skadden, Arps, Slate, Meagher \& Flom LLP, 29.4.2013, available at: http://www.skadden.com/insights/ increasing-appeal-and-novel-use-bilateral-investment-treaties. 
over ICSID jurisdiction in sovereign bond disputes ${ }^{4}$. The decisions show unprecedented deference towards sovereign bondholders, considerably broadening the scope of ICSID jurisdiction. Their possible ramifications involve opening a floodgate for the uncontrolled inflow of bondholders' mass claims and thus involving ICSID arbitration in the sovereign debt restructuring process. It may have impact upon the whole global economic order, considerably undermining sovereign debt restructuring efforts at a time of global financial crisis.

The aim of this comment is to elaborate on the legal implications of the Abaclat and Ambiente Ufficio decisions, with regard to the recognition of sovereign bonds as investments and the assessment of the treaty character of sovereign bondholders' claims ${ }^{5}$. Moreover, this comment evaluates the possible effects of these decisions on the sovereign debt restructuring process.

\section{Factual background}

The Argentina default on its external debt of 2001 was unprecedented, in the sense that never before had any state defaulted on as much as 100 billion (bln) dollars ${ }^{6}$. This deferral led to the longest and most complex restructuring process in history ${ }^{7}$.

4 The International Centre for Settlement of Investment Disputes (ICSID) is part of the World Bank group. The Centre operates under the Convention of 18.3.1965 on the Settlement of Investment Disputes between States and Nationals of Other States ("the ICSID Convention" or "the Convention"). It provides a basic procedural framework for numerous arbitral tribunals deciding investment cases on an ad hoc basis. See: https:// icsid.worldbank.org/ICSID/ICSID/AboutICSID_Home.jsp. Text of the ICSID Convention is available on: https://icsid.worldbank.org/ICSID/ICSID/RulesMain.jsp.

5 On the key holdings of the Abaclat decision, see: E. Norton, International investment arbitration and the European debt crisis, 'Chicago Journal of International Law' 2012, Vol. 13, No. 1, p. 291, at p. 298.

6 On 23.12.2001 Argentina announced deferral of 100 bln dollars owed to both non-Argentine and Argentine creditors. See: Abaclat and others v. the Argentine Republic, Decision on jurisdiction and admissibility, supra, at para 58.

7 E. Norton, International investment arbitration and the European debt crisis, op. cit., at. p. 294. 
The majority of Argentina's public debt originated from bonds issued between 1991 and $2001^{8}$. Argentina estimated that, by the end of 2002, as much as 76 bln dollars of its total 136 bln dollars in public debt was owed to public bondholders ${ }^{9}$. 13,5 bln dollars of this amount was owed to Italian detail bondholders (approximately 600,000 persons) ${ }^{10}$.

When Argentina began negotiations with external creditors, Italian bondholders were represented by the Task Force Argentina ("TFA") - an organization comprising major Italian banks ${ }^{11}$. Unable to reach a compromise with its creditors ${ }^{12}$, Argentina announced the launch of a bond exchange option, available to all foreign bondholders on a takeit-or-leave-it basis ${ }^{13}$. It was a unilateral offer by Argentina to external bondholders, allowing the latter to exchange their bonds for new ones having a reduced principal or lower interest rate ${ }^{14}$. The offer was followed by new legislation which prohibited the government from reopening the negotiation process in the future or entering into any settlements with creditors refusing to participate in the exchange offer ${ }^{15}$. The objective of the regulation was to achieve a high participation of creditors in the exchange offer and to ensure participating bondholders that they will not lose out on any better deal in the future ${ }^{16}$. However, it closed the door for

8 During that decade Argentina collected over 186 bln dollars by the issuance of sovereign bonds, see: Abaclat and others v. the Argentine Republic, Decision on jurisdiction and admissibility, supra, at para 50.

9 Ibidem, at para 63.

10 Ibidem, at para 64.

11 Ibidem, at para 65.

12 Argentina adopted a hard line towards creditors, insisting on a large write-down for private creditors, see: J. F. Hornbeck, Argentina's Defaulted Sovereign Debt: Dealing with the "Holdouts", 'Congressional Research Service', 24.10.2010, p. 1, at p. 4, available at: http://assets.opencrs.com/rpts/R41029_20100924.pdf.

$13 \mathrm{~J}$. Beess und Chrostin, Sovereign debt restructuring and mass claims arbitration before the ICSID, the Abaclat case, 'Harvard International Law Review' 2012, Vol. 53, No. 1, p. 505, at. p. 506 .

14 Abaclat and others v. the Argentine Republic, Decision on jurisdiction and admissibility, supra, at para 77.

15 Ibidem, at para 78-79; E. Norton, International investment arbitration and the European debt crisis, op. cit., at p. 297; J.F. Hornbeck, Argentina's Defaulted Sovereign Debt: Dealing with the "Holdouts", op. cit., at p. 4.

16 J.F. Hornbeck, Argentina's Defaulted Sovereign Debt: Dealing with the "Holdouts", op. cit., at p. 4. 
Argentina negotiating future settlements with those creditors who decided not to take part in the exchange offer.

Despite the relatively high level of participation in the exchange offer ${ }^{17}$, the amount of debt held by the holdout creditors ("holdouts") amounted to 25 bln dollars ${ }^{18}$. Many holdouts decided to sue Argentina before national courts, mainly those in the USA and Germany ${ }^{19}$.

Although proceedings before national courts had some potential for success as regards Argentinian assets located abroad ${ }^{20}$, it was hardly credible that they would result in the successful enforcement of awards in Argentina. Therefore, one of the possible solutions for holdouts was recourse to international investment arbitration. ICSID arbitration appeared as a particularly plausible option for holdouts, since ICSID arbitral awards are enforceable in the host state as final rulings of the courts of such states, without the need for formal recognition ${ }^{21}$. This is

17 75\% of the holdouts have participated in the offer, see: Abaclat and others $v$. the Argentine Republic, Decision on jurisdiction and admissibility, supra, at para 80.

18 K. Halverson Cross, Arbitration as a Means of Resolving Sovereign Debt Disputes, 'American Review of International Arbitration' 2006, Vol. 17, No. 3, p. 335, at p. 335; J. Simões, Sovereign bond disputes before ICSID tribunals: lessons from the Argentina crisis, 'Law \& Business Review of the Americas' 2011, Vol. 17, No. 4, p. 683, at p. 684.

19 Abaclat and others $v$. the Argentine Republic, Decision on jurisdiction and admissibility, supra, at para 82.

20 Holdout bondholders have successfully frozen over two billion dollars of Argentina's assets in the USA through domestic litigation, see R.M. Ziff, The Sovereign Debtor's Prison: Analysis of the Argentine Crisis Arbitrations and the Implications for Investment Treaty Law, 'Richmond Journal of Global Law and Business' 2011, Vol. 10, p. 345, at p. 377.

21 See Article 54 (1) of the ICSID Convention: "Each Contracting State shall recognize an award rendered pursuant to this Convention as binding and enforce the pecuniary obligations imposed by that award within its territories as if it were a final judgment of a court in that State". Non-ICSID arbitral awards are not automatically recognized and they require recognition, for example under the United Nations Convention on the Recognition and Enforcement of Foreign Arbitral Awards. See: T. Mikhailova, F. Mac Johnston, Enforcing Arbitral Awards Against Sovereigns: Process and Pitfalls, 'Robert Wray PLLC newsletter', December 2009, available at: http://www.robertwraypllc.com/enforcingarbitral-awards-against-sovereigns-process-and-pitfalls. On the advantages of investment arbitration with regard to sovereign bond disputes see: T. W. Wälde, The Serbian Loans Case: A Precedent for Investment Treaty Protection of Foreign Debt? [in:] T. Weiler (ed.) 'International Investment Law and Arbitration: Leading Cases from the ICSID, NAFTA, Bilateral Treaties and Customary International Law', Cameron May, London 2005, p. 383, at pp. 402-403. 
why ICSID arbitration was recommended to the holdouts by the Global Committee of Argentina Bondholders ${ }^{22}$.

In September 2006 almost 180.000 Italian bondholders represented by the TFA filed a request for arbitration with the ICSID ${ }^{23}$. The case was registered under the name Giovanna a Beccara and others v. the Argentine Republic and subsequently renamed as Abaclat and others v. the Argentine Republic. The number of claimants decreased to approximately 60.000 persons after a considerable number of creditors decided to participate in the Argentina second exchange offer of $2010^{24}$. Given the large number of claimants, the Abaclat tribunal was significantly undermined in its efforts to effectively proceed with the case. Nevertheless, the tribunal closed the jurisdictional phase of proceedings and issued a Decision on jurisdiction and admissibility on 11.08.201125.

Apart from the Abaclat case, two other lawsuits were brought against Argentina by the smaller groups of Italian bondholders. The first, named Giovanni Alemanni and others v. Argentine Republic, is still pending and has not undergone the jurisdictional phase to date ${ }^{26}$. The second, Ambiente

22 The Global Committee of Argentina Bondholders, GCAB Releases Legal Memorandum Summarizing Recent Argentine Legislation and Bondholder Remedies, New York 15.02.2005, available at: http://www.prnewswire.com/news-releases/gcab-releases-legal-memorandumsummarizing-recent-argentine-legislation-and-bondholder-remedies-54081267.html.

${ }^{23}$ Abaclat and others v. the Argentine Republic, Decision on jurisdiction and admissibility, supra, at para 90; J. Beess und Chrostin, Sovereign debt restructuring and mass claims arbitration before the ICSID, the Abaclat case, op. cit., at p. 507. However, some other sources indicate the number of 195.000 claimants, see: J. Simões, Sovereign bond disputes before ICSID tribunals: lessons from the Argentina crisis, op. cit., at p. 684; The Task Force Argentina, ICSID Registers Request for Arbitration Brought By 195,000 Italian Investors Against Argentina, press release of 9.2.2007, available at: http://www.tfargentina. it/download/TFA\%20Press\%20Release\%209\%20Feb\%202007.pdf.

24 Abaclat and others v. the Argentine Republic, Decision on jurisdiction and admissibility, supra, at para 97 and 216. However, it is said that, after the exchange offer of 2010, approx. 1 bln dollars of ICSID claims against Argentina remain, see: United Nations Conference on Trade and Development (UNCTAD), Sovereign Debt Restructuring and International Investment Agreements, 'International Investment Agreements Issues Note' 2011, No. 2, p. 1, at p. 3, available at: http://unctad.org/en/Docs/webdiaepcb2011d3_en.pdf.

25 See FN 1.

26 Giovanni Alemanni and others v. the Argentine Republic, ICSID Case no ARB/07/8, registered 27.3.2007, see: https://icsid.worldbank.org/ICSID/FrontServlet?requestType= GenCaseDtlsRH\&actionVal=ListPending. 
Ufficio S.p.A. and others v. Argentine Republic, formerly known as Giordano Alpi and others $v$. Argentine Republic, has recently reached the merits phase after a Decision on jurisdiction and admissibility was issued on 8.2.2013 ${ }^{27}$.

The Decisions on jurisdiction and admissibility in the Abaclat and Ambiente Ufficio cases are based on analogous premises. There are substantial parallels between these cases, as regards their factual background, the argumentation deployed by the parties to the proceedings and the conclusions of the tribunals ${ }^{28}$. The conclusions of the tribunals, in particular, share much in common. The Ambiente Ufficio tribunal even went so far as to refer to the Abaclat tribunal as its "sister Tribunal" 29 It held that, due to the "special, particularly close relationship between the present cases and the Abaclat cases" 30 , it will not "hesitate to benefit, where applicable and appropriate, from the reasoning of the Abaclat Tribunal"31.

In light of the above similarities, both Decisions will form the subject of analysis within this comment. The comment concentrates on the controversial questions of jurisdiction rationae materiae over sovereign bondholders' claims and the assessment of the treaty character of such claims. It leaves aside the procedural question of the admissibility of mass claims in the ICSID arbitration, which is worthy of separate attention ${ }^{32}$.

27 See FN 2. See also L. Peterson, Argentina faces a third treaty claim by hold-out bond-holders; Experts differ as to prospects, 'Investment Arbitration Reporter' of 7.4.2008, available at: http://www.iareporter.com/articles/20091001_54.

28 See: Ambiente Ufficio S.p.A. and others v. the Argentine Republic, Decision on jurisdiction and admissibility, supra, at para 10.

29 Ibidem.

30 Ibidem, at para 11.

31 Ibidem, at para 12 .

32 Among the articles dealing with this issue, see: J. Beess und Chrostin, Sovereign debt restructuring and mass claims arbitration before the ICSID, the Abaclat case, op. cit.; H. van Houtte, B. McAssey, Abaclat and others v Argentine Republic. ICSID, the BIT and Mass Claims, 'ICSID Review' 2012, Vol. 27, No. 2, p. 231, at pp. 231-236; S. I. Strong, Mass Procedures as a Form of "Regulatory Arbitration" - Abaclat v. Argentine Republic and the International Investment Regime, 'The Journal of Corporation Law' 2013, Vol. 38, No. 2, p. 9, at pp. 9-81, available at: http://papers.ssrn.com/sol3/papers.cfm?abstract_ $\mathrm{id}=2146626$. 


\section{Analysis of the Abaclat and Ambiente Ufficio decisions}

\subsection{The question of the existence of an investment}

The most arguable question ruled upon by the arbitral tribunals in the Abaclat and Ambiente Ufficio decisions was the qualification of financial instruments held by the claimants as investments under the ICSID Convention and Article 1 (c) Argentina-Italy BIT. This question touched upon not only such controversial and widely commented issue as the qualification of sovereign bonds as investments on the grounds of the ICSID Convention ${ }^{33}$, but also upon some specific issues arising on the grounds of these particular cases.

\subsubsection{The legal nature of financial instruments held by the claimants as investments}

It should be emphasized that, both in the Abaclat and Ambiente Ufficio cases, the claimants based their claims not on the sovereign bonds issued by Argentina but on the security entitlements attached to these bonds ${ }^{34}$. This became a major source of contention between the parties to the arbitral proceedings. Two questions arose on this ground: whether security entitlements constituted investments in their own right and whether they formed part of an economic operation constituting an investment.

\subsubsection{Security entitlements as investments in their own right}

The legal character of the security entitlements held by the claimants is not entirely clear. During the Abaclat proceedings, Argentina contended that the security entitlements "were not created and are not governed by Argentine law and are enforceable outside Argentina" 35 . They were

33 See particularly: M. Waibel, Opening Pandora's Box: Sovereign Bonds in International Arbitration, 'American Journal of International Law' 2007, Vol. 101, No. 4, p. 701, at pp. 718-732.

34 Therefore, the claimants in the Abaclat and the Ambiente Ufficio cannot be regarded as bondholders in a strict sense of this term.

35 Abaclat and others v. the Argentine Republic, Decision on jurisdiction and admissibility, supra, at para 234 (v). 
issued not by Argentina but by Italian banks after their purchase of the Argentinian bonds. Argentina contended that: "security entitlements have only a remote and attenuated relationship to the underlying bonds through secondary market transactions that violated relevant law" ${ }^{36}$.

The first question to be answered within this issue is whether the legal nature of security entitlements is similar to that of options. It has been emphasized that options are not investments ${ }^{37}$ because they "do not satisfy the requirements for the economic materialisation of an investment" 38 . Options are not linked to ownership of any underlying asset, but merely evidence a claim conditioned on the economic performance of a specific asset without any direct claim to the asset itself. In contrast to options, bonds are debt securities representing a direct claim for a certain amount of money. They play a similar role to loans.

The proprietary nature of investment distinguishes it from other transactions. As stated by Professor Zachary Douglas: "The key to distinguishing covered investment securities from other interests in stocks and shares that do not attract investment treaty protection is the proprietary nature of the interest" 39 . Hence, to qualify as an investment, security entitlements should grant their holders contractual claims to any underlying assets.

Security entitlements give their holders a claim for payment of the value of the security entitlements. This value is fully dependent on the performance of bonds as the underlying assets for security entitlements. Hence, security entitlements are a kind of derivative securities, having no value independent from the bonds themselves ${ }^{40}$. It appears that the issuance of security entitlements does not entail any transfer of title to bonds. The holders of security entitlements do not acquire any direct claims to the bonds as the underlying assets for security entitlements.

36 Ibidem, at para 307 (i).

37 PSEG Global Inc., The North American Coal Corporation, and Konya Ilgin Elektrik Üretim ve Ticaret Limited Sirketi v. Republic of Turkey, Decision on jurisdiction of 4.06.2004, ICSID Case no ARB/02/5, at para 189.

38 Z. Douglas, The International Law of Investment Claims, Cambridge University Press, Cambridge 2009, p. 1, at p. 185.

39 Ibidem, at p. 182.

40 Abaclat and others v. the Argentine Republic, Decision on jurisdiction and admissibility, supra, at para 358. 
Moreover, they do not acquire any claim to money paid by the issuer of security entitlements in exchange for the bonds. Consequently, the nature of security entitlements is similar to options and they do not qualify as investments.

However, in the circumstances of the Abaclat and Ambiente Ufficio cases, there are several arguments in favor of the qualification of security entitlements as investments. During the arbitral proceedings, it was emphasized by the arbitral tribunals that the Argentinian bonds "were always meant to be divided into smaller negotiable economic values, i.e. securities" 41 and that private persons were expected to "purchase shares of the bonds on the secondary market, in the form of security entitlements, since otherwise the bond could not have been successfully issued in the first place" ${ }^{42}$. The Abaclat tribunal pointed out that:

It is undisputed that Claimants, as owners of security entitlements, have a potential contract claim against Argentina for payment of the principal amount and interest of such security entitlement. This relationship is of a private and contractual nature, subject to the terms and conditions of the bonds, which vary depending on the bond series ${ }^{43}$.

It stems from these considerations that there existed a nexus between the Argentinian bonds and the security entitlements held by the claimants. Both tribunals suggested that the legal character of the security entitlements was proprietary in nature, analogously as in case of bonds. Yet, in order to find that the holders of the security entitlements had been given any property rights by Argentina, the following conditions needed to be fulfilled. Firstly, Argentina should have agreed to the "division" of its bonds into the security entitlements. Secondly, Argentina's bondholders should have been deprived of their rights to repayment under the proportional parts of the bonds divided into the security entitlements. Thirdly, the holders of the security entitlements should have been given direct rights to sue Argentina for repayment of the principal amount

41 Ibidem.

42 Ambiente Ufficio S.p.A. and others v. the Argentine Republic, Decision on jurisdiction and admissibility, supra, at para 425.

43 Abaclat and others v. the Argentine Republic, Decision on jurisdiction and admissibility, supra, at para 319. 
and interests of the security entitlements and Argentina should have admitted these rights. Lastly, the principal amount and interests of the security entitlements should have represented the same value as that of the Argentinian bonds.

However, there is little evidence for this assumption against the factual background of both cases. As observed by Santiago Torres Bernárdez in his Dissenting Opinion to the Ambiente Ufficio decision: "No factual and/or legal causality connection between the issuance of the bonds and the issuance of the security entitlements has been proven by Claimants in the instant proceeding" 44 . It seems that the argumentation of the Abaclat and Ambiente Ufficio tribunals was based mainly on the fact that Argentina admitted its contractual liability under the security entitlements, engaging their holders in the exchange offer of 201045. However, there is no evidence that the bonds issuance process involved $a b$ initio the issuance of the security entitlements and that Argentina agreed upon the conditions of such issuance. Rather, Argentina subsequently recognized the claims of the security entitlements' holders.

Although the security entitlements represented a proportional part of bonds held by the Italian banks, their link with the money paid by these banks to Argentina in exchange for the bonds was too remote to qualify them as investments. The security entitlements did not evidence any direct claim for payment of the principal amount of Argentinian bonds. They represented no direct link with funds received by Argentina on the issuance of bonds ${ }^{46}$ and they were legally remote from these funds. In fact, they played a similar role to options. They were hinged upon the performance of bonds and not upon the money paid to Argentina in

44 S. Torres Bernárdez, Dissenting Opinion to the Ambiente Ufficio S.P.A. and Others v. the Argentine Republic Decision on Jurisdiction and Admissibility of 2.5.2013, at para 157.

45 Abaclat and others $v$. the Argentine Republic, Decision on jurisdiction and admissibility, supra, at para 360.

46 Professor Georges Abi-Saab pointed out in his Dissenting Opinion to the Abaclat decision that in case of the claimants' security entitlements there is "no visible relation to the lump-sum received by Argentina from the underwriters at issuance" (G. Abi-Saab, Abaclat and Others v. Argentina, Decision on jurisdiction and admissibility, Dissenting Opinion of 28.10.2011, at para 71). 
exchange for such bonds They had no value per se and were not linked with ownership of any underlying assets. As a consequence, they did not constitute an investment ${ }^{47}$.

The Abaclat tribunal reached the opposite conclusion, stating that "bonds and security entitlements therein cannot be regarded as two separate investments relating to different rights or values" ${ }^{48}$. Similarly, the Ambiente Ufficio tribunal accepted jurisdiction over the security entitlements and stated that: "for the purpose of identifying the protected investment in the present case; the distinction between bonds and security entitlements has no particular significance" 49 .

\subsubsection{Security entitlements as a part}

of the economic operation constituting an investment

Having accepted jurisdiction over the security entitlements, the Abaclat and Ambiente Ufficio tribunals applied the "overall operation" principle, pursuant to which the qualification of debt transactions as investments should be assessed in light of the broader operation of which they form a part. As stated by an arbitral tribunal in the CSOB v. The Slovak Republic case:

Hence, a dispute that is brought before the Centre must be deemed to arise directly out of an investment even when it is based on a transaction which, standing alone, would not qualify as an investment under the Convention,

47 The legal remoteness of security entitlements resembles the factual background in the case of Gruslin v. Malaysia (Philippe Gruslin v. Malaysia, Award of 27.11.2000, ICSID Case no ARB/99/3). As Professor Zachary Douglas has stated: "Malaysia contended that Gruslin had made no investment in the KLSE securities because, as a holder of units in the EAMEC fund, he had no severable individual property right to the investments made by that fund in Malaysia. (The tribunal had correctly ruled that the territorial requirement for a covered investment necessitated that Gruslin had rights to the securities listed on the KLSE in Malaysia in addition to rights in the EAMEC fund in Luxembourg.) Instead, all Gruslin had acquired as a unit holder were contractual rights to the proper administration of the mutual fund" (Z. Douglas, The International Law of Investment Claims, op. cit., at p. 182).

48 Abaclat and others v. the Argentine Republic, Decision on jurisdiction and admissibility, supra, at para 360.

49 Ambiente Ufficio S.p.A. and others v. the Argentine Republic, Decision on jurisdiction and admissibility, supra, at para 423. 
provided that the particular transaction forms an integral part of an overall operation that qualifies as an investment" ${ }^{\text {"50 }}$.

Using similar wording as the CSOB tribunal, the Abalcat and Ambiente Ufficio tribunals argued that bonds and security entitlements constitute part of one and the same economic operation and that they only make sense together51. In the Ambiente Ufficio tribunal's view: "To seek to split up bonds and security entitlements (...) would ignore the economic realities and the very function, of the bond issuing process" 52 . According to both tribunals, even if considering that security entitlements alone do not qualify as investments, they form a part of an overall economic operation that constitutes an investment as a whole.

In light of the above considerations, there is no basis for such a conclusion. It appears that the issuance of the security entitlements by Italian banks was in no way advanced by Argentina. Security entitlements were issued independently by Italian banks (without any contractual commitment of Argentina). They were traded on different markets from those on which the Argentinian bonds were traded ${ }^{53}$. There is no evidence of the transfer of legal title to bonds between bondholders and the holders of the security entitlements. As emphasized by Santiago Torres Bernárdez in his Dissenting Opinion to the Ambiente Ufficio decision: “"bonds» and «security entitlements» are materially and legally different «financial products» issued at different moments of time, in different markets and by two different juridical persons" 54 .

To regard sovereign bonds and security entitlements as part of one single economic operation, in the absence of the explicit consent of the

50 Ceskoslovenska Obchodni Banka, A.S. (CSOB) v. The Slovak Republic, Decision of the Tribunal on objections to jurisdiction of 24.05.1999, ICSID Case no ARB/97/4, at para 72 .

51 Abaclat and others v. the Argentine Republic, Decision on jurisdiction and admissibility, supra, at para 359; Ambiente Ufficio S.p.A. and others v. the Argentine Republic, Decision on jurisdiction and admissibility, supra, at para 423.

52 Ambiente Ufficio S.p.A. and others v. the Argentine Republic, Decision on jurisdiction and admissibility, supra, at para 425.

53 G. Abi-Saab, Abaclat and Others v. Argentina, Decision on Jurisdiction and Admissibility, Dissenting Opinion, supra, at para 71.

54 S. Torres Bernárdez, Dissenting Opinion to the Ambiente Ufficio S.P.A. and Others v. the Argentine Republic Decision on Jurisdiction and Admissibility, supra, at para 154. 
state, would mean that sovereign bondholders would be completely free in the issuance of derivative securities on the secondary markets and that all such instruments should receive protection under investment treaties. The holders of such instruments could issue other derivative financial instruments, structure them and tie them to other financial instruments without any control of the state which issued the bonds. This would lead to the infinite broadening of the scope of potential claimants in investment cases.

\subsubsection{Sovereign bonds and security entitlements as investments under the ICSID Convention}

\subsubsection{The "double-barrelled" test for the existence of an investment under Article 25 the ICSID Convention}

Interpretation of the notion of investment, within the meaning of Article 25 ICSID Convention, remains one of the most controversial questions of international investment law. It is hardly possible to accept the view that the notion of investment has no inherent meaning on the grounds of the ICSID Convention. This would lead to the conclusion that Article 25 ICSID Convention is a meaningless provision and that the parties to investment disputes possessed total discretion as regards what kind of disputes they can bring to ICSID arbitration ${ }^{55}$. Hence, it is generally accepted that the notion of investment has an inherent meaning on the grounds of the ICSID Convention ${ }^{56}$ and that this meaning imposes

55 See Joy Mining Machinery Limited v. The Arab Republic of Egypt, Award on jurisdiction of 6.08.2004, ICSID Case no ARB/03/11, at para 50: "The parties to a dispute cannot by contract or treaty define as investment, for the purpose of ICSID jurisdiction, something which does not satisfy the objective requirements of Article 25 of the Convention. Otherwise Article 25 and its reliance on the concept of investment, even if not specifically defined, would be turned into a meaningless provision"; Mr. Saba Fakes v. Republic of Turkey, Award of 14.07.2010, ICSID Case no ARB/07/20, at para 108: "The Tribunal believes that an objective definition of the notion of investment was contemplated within the framework of the ICSID Convention, since certain terms of Article 25 would otherwise be devoid of any meaning".

56 However, a subjective approach would indicate that the notion of investment does not have any inherent meaning under the ICSID Convention. Proponents of the subjectivist theory assert that the task of defining investment was left to the parties to an investment dispute. See: M.C.I. Power Group L.C. \& New Turbine, Inc. v. Republic of Ecuador, Award of 31.07.2007, ICSID Case no ARB/03/6, at para 159: "The Tribunal 
some jurisdictional limits on the ICSID tribunals. Each transaction must fulfil a "double-barrelled" test, entailing qualification as an investment under the ICSID Convention and the relevant investment agreement (such as the $\mathrm{BIT})^{57}$.

There is no consensus on the exact scope of the "double-barrelled" test. Some tribunals relied on the so called Salini test and introduced several jurisdictional requirements for the existence of an investment ${ }^{58}$, while the other dispensed from the Salini test, looking for a different characterization of an investment under the ICSID Convention.

What is common for the "double-barrelled" test approach is the conviction that the ICSID Convention sets jurisdictional outer limits of the notion of investment ${ }^{59}$. It does not relate to unspecified categories of

notes that numerous arbitral precedents confirm the statement in the Report of the Executive Directors of the World Bank that the Convention does not define the term "investments « because it wants to leave the parties free to decide what class of disputes they would submit to the ICSID".

57 See Malaysian Historical Salvors SDN BHD v. Malaysia, Award on jurisdiction of 17.05.2007, ICSID Case no ARB/05/10, at para 55: "Under the double-barrelled test, a finding that the Contract satisfied the definition of "investment" under the BIT would not be sufficient for this Tribunal to assume jurisdiction, if the Contract failed to satisfy the objective criterion of an "investment" within the meaning of Article 25".

58 International arbitral tribunal in Salini v. Morocco. The Decision on jurisdiction identified four criteria of the existence of an investment: contribution, a certain duration, participation in the risk of the transaction and contribution to the host state economic development. See: Salini Costruttori S.p.A. and Italstrade S.p.A. v. Kingdom of Morocco, Decision on jurisdiction of 23.07.2001, ICSID Case no ARB/00/4, at p. 52. The Salini criteria were originally formulated by Professor Christoph Schreuer in his Commentary to the ICSID Convention of 1996 and they included an additional criterion of the regularity of profit and return. See: $\mathrm{Ch}$.H. Schreuer, Commentary on the ICSID Convention, 'ICSID Review - Foreign Investment Law Journal' 1996, Vol. 11, No. 2, p. 318, at. p. 372. Contrary to Professor Schreuer's intent they served for numerous arbitral tribunals as jurisdictional requirements for the existence of an investment. As Professor Michael Waibel has observed: "His original intent was purely descriptive, yet many ICSID tribunals gave these elements normative content" (M. Waibel, Opening Pandora's box: sovereign bonds in international arbitration, op.cit., at p. 723).

59 See J. Ho, The Meaning of 'Investment' in ICSID Arbitrations, 'Arbitration International' 2010, Vol. 26, No. 4, p. 633, at pp. 641-644, explaining that the term "outer limits" was first coined by A. Broches in History of the ICSID Convention, ICSID, Washington 1968, Vol. II-1, at p. 34. See also Judge Mohamed Shahabuddeen, Dissenting Opinion to the Malaysian Historical Salvors, SDN, BHD v. The Government of Malaysia, Decision 
economic contributions but, rather, to specific categories of investments. Since the ICSID Convention does not provide clear guidance on the scope of its outer limits, the question arises as to whether such limits cover sovereign bonds and security entitlements. As Professor Georges Delaume has remarked: "From the origin of the Convention [it has been assumed] that longer term loans were included in the concept of «investment»" 60 . However, this traditional view is currently subject to criticism with strong opinions arguing against the qualification of debt instruments as investments ${ }^{61}$.

In their decisions, the Abaclat and Ambiente Ufficio tribunals were confronted with precisely these interpretative problems.

\subsubsection{Broad meaning of an investment under the ICSID Convention}

a) Identification of an investment with the economic contribution by the Abaclat tribunal

The Abaclat and Ambiente Ufficio tribunals applied the broad interpretation of the notion of investment under the ICSID Convention.

on the Application for Annulment of 16.04.2009, ICSID Case no ARB/05/10, at para 11: "Where it becomes necessary to find the outer limits, as it is here, they must be found - if necessary, by an implication that the parties accepted that their admittedly wide competence to agree on the contents of an ICSID investment assumed that that competence was nevertheless not limitless, that it was exercisable within some ultimate boundaries".

Compare with: M. Waibel, Sovereign Defaults before International Courts and Tribunals, Cambridge University Press, Cambridge 2011, p. 1, at p. 215: "Access to ICSID dispute settlement cases is conditioned on Article 25's 'outer limits'. In all cases transaction needs to fall within Article 25's 'objective core”; S.M. Schwebel, Justice in International Law, Cambridge University Press, Cambridge 2011, p. 1, at p. 284: "These fundaments, and the assumption that the term "investment" does not mean "sale", appear to comprise "the outer limits," the inner content of which is defined by the terms of the consent of the parties to ICSID's jurisdiction".

60 G.R. Delaume, ICSID and the Transnational Financial Community, 'ICSID Review Foreign Investment Law Journal' 1986, Vol. 1, No. 2, p. 237, at p. 242, cit. by M. Waibel, Opening Pandora's Box: Sovereign Bonds in International Arbitration, op. cit., at p. 722.

61 See: M. Waibel, Opening Pandora's Box: Sovereign Bonds in International Arbitration, op. cit.; Z. Douglas, The International Law of Investment Claims, op. cit., at pp. 180-183; M. Waibel, Sovereign Defaults before International Courts and Tribunals, op. cit., at pp. 209-251 . 
The Abaclat tribunal focused on the "value" of the claimants' contribution and identified investment with the economic contribution ${ }^{62}$. This approach disregards the major fact that the sole economic contribution does not amount to an investment. What is protected within the ICSID Convention are investments in the economic as well as the legal sense. As Professor Zachary Douglas has clearly pointed out, "it is essential that an investment have both the requisite legal and economic characteristics" ${ }^{3}$. The Abaclat tribunal focused solely on the economic characteristics of an investment. It did not apply the distinction between instrumentum and negotium, that is the instrument that registers and vehicles a transaction and the transaction itself ${ }^{64}$. Yet, what distinguishes the term "investment" from such terms as "transaction" or "contribution" is the legal characteristic of an investment. Many investments, such as intellectual property rights, do not entail any transfer of capital and it is often hard to ascertain the exact value of their economic contribution.

The Abaclat tribunal dispensed from the legal characteristic requirement on the grounds of Article 25 ICSID Convention, focusing solely on the economic aspect of an investment. Adopting the "doublebarrelled" test, it stated that the only requirement regarding the "contribution" was whether it led to the creation of the "value" that was protected under the BIT ${ }^{65}$. Therefore, the tribunal practically abandoned the "double-barrelled" test and based its argumentation solely on the contribution aspect of the BIT definition ${ }^{66}$.

62 The Abaclat tribunal used the term "contribution" to describe investment: "Consequently, the tribunal finds that Claimants' purchase of security entitlements in Argentinian bonds constitutes a contribution which qualifies as 'investment' under Article 25 ICSID Convention". See: Abaclat and others v. the Argentine Republic, Decision on jurisdiction and admissibility, supra, at para 364 and 367.

${ }_{63}$ Z. Douglas, The International Law of Investment Claims, op. cit., at p. 163.

${ }^{64}$ See: G. Abi-Saab, Abaclat and Others v. Argentina, Decision on Jurisdiction and Admissibility, Dissenting Opinion, supra, at para 91.

${ }^{65}$ C. Lévesque, Case Comment, Abaclat and Others v Argentine Republic, The Definition of Investment, 'ICSID Review' 2012, Vol. 27, No. 2, p. 247, at p. 249.

${ }^{66}$ What is even more striking is the fact that, according to the tribunal, the definition of investment in the BIT is "of course based on the premise of the existence of such contribution". See: Abaclat and others v. the Argentine Republic, Decision on jurisdiction and admissibility, supra, at para 347 (i). 
In its analysis, the Abaclat tribunal did not pay attention to the fact that the claimants had paid no money to Argentina that could constitute an economic contribution. The only recourse to the legal characteristic of an investment was the tribunal's finding that the "value" generated by the claimants' contribution was the right attached to the security entitlements to claim reimbursement of the funds from Argentina. However, the tribunal did not examine whether this "right" was granted to the claimants by Argentina or by the Italian banks.

b) Distinguishing investments from the single commercial transactions by the Ambiente Ufficio tribunal

The Ambiente Ufficio tribunal relied on the rules of interpretation established in the Vienna Convention of the Law of Treaties ${ }^{67}$ to find that the notion of investment in the ICSID Convention should be interpreted broadly. According to the tribunal, the only jurisdictional constraints imposed on investments by Art. 25 ICSID Convention relate to transactions that do not qualify as economic activities ${ }^{68}$. The tribunal did not elaborate on the exact scope of economic activities that should receive protection under the ICSID Convention. It only pointed out that single commercial transactions remain outside the scope of protected investments ${ }^{69}$. It emphasized that bonds and security entitlements are in no way comparable to single commercial transactions without, however, analysing this issue in any greater depth ${ }^{70}$.

67 Vienna Convention of the Law of Treaties of 23 May 1969. Text of the Convention is available at: http://untreaty.un.org/ilc/texts/instruments/english/ convention s/1_1_1969.pdf.

68 See: Ambiente Ufficio S.p.A. and others v. Argentine Republic, Decision on jurisdiction and admissibility, supra, at para 470: "the term «investment» in Art. 25 of the ICSID Convention, when interpreted in accordance with its ordinary meaning, in its context and in the light of the object and purpose of the Convention, is to be given a broad meaning, i.e. with jurisdictional limits arising from this provision only at the outer margins of economic activity".

69 See ibidem: "...there are good reasons to leave the single commercial transactions such as the delivery of a single load of cars outside the concept of investment..."

70 Ibidem, at para 471. 
It is generally accepted that ordinary commercial transactions are excluded from the scope of the ICSID Convention ${ }^{71}$. Despite the Ambiente Ufficio tribunal's silence on this issue, serious doubts exist as to whether or not bonds and security entitlements constitute commercial transactions. In dissenting opinions delivered in the Abaclat and Ambiente Ufficio decisions it was emphasized that, by selling sovereign bonds, Argentina participated in the transactions as a commercial actor ${ }^{72}$. As financial instruments, the bonds and the security entitlements were capable of being traded on financial markets within seconds at the touch of the button, without any involvement of Argentina ${ }^{73}$. It appears that, from the perspective of their holders, the acquisition of the bonds and the security entitlements by the claimants could be nothing more but a single commercial transaction. To defend its conclusions, the Ambiente Ufficio tribunal could have accented the economic unity of the bonds issuance process and the involvement of the public interest on the side of Argentina. In doing so, it could have applied the Fedax public interest test.

In Fedax v. Venezuela, the ICSID tribunal indicated certain characteristics of promissory notes, such as: the possibility that they would be transferred and endorsed to subsequent holders, their denomination in foreign currency that enables their international circulation and their character as negotiable instruments within secondary market ${ }^{74}$. Despite these peculiarities of promissory notes, the tribunal distinguished them from ordinary commercial transactions on the grounds of the "fundamental public interest" involved in the issuance of promissory notes ${ }^{75}$.

71 SGS Société Générale de Surveillance S.A. v. Islamic Republic of Pakistan, Decision of the Tribunal on Objections to Jurisdiction of 6.4.2003 r., ICSID case no ARB/01/13, at FN 153.

72 S. Torres Bernárdez, Dissenting Opinion to the Ambiente Ufficio S.P.A. and Others v. the Argentine Republic Decision on Jurisdiction and Admissibility, supra, at para 186.

73 G. Abi-Saab, Abaclat and Others v. Argentina, Decision on Jurisdiction and Admissibility, Dissenting Opinion, supra, at para 57 and 70.

74 Fedax N.V. v. the Republic of Venezuela, Decision of the Tribunal on Objections to Jurisdiction of 11.7.1997, ICSID Case no ARB/96/3, at para 39.

75 Ibidem, at para 42: "It is quite apparent that transactions involved in this case are not ordinary commercial transactions and indeed involve a fundamental public interest". 
The Fedax public interest test appears to be a reasonable tool in distinguishing investments from other, non-investment transactions ${ }^{76}$. It allows one to tie investments with state purposes and policies. It is much broader than the economic development criterion derived from the Salini test ${ }^{77}$. Contrary to the Salini criterion, it focuses on the purpose of investment transactions, as opposed to their influence on the state economy. It reflects the view that many transactions contribute to state development in a much broader sense. They allow for the preservation of the state economy and secure this economy from internal and external crises. This is a general role of sovereign bonds issued with the aim of financing the public treasury and maintaining a proper balance of payments within the state budget. Despite the fact that their role in the state economy can hardly be overestimated, it is often difficult to precisely estimate this impact on state economic development. Bearing in mind these peculiarities of sovereign bonds, it is obvious that they involve a fundamental public interest and are closely interrelated with the state economy and development.

From the perspective of investors, such bonds do not differ significantly from ordinary financial instruments that are tradable on financial markets. Yet, from the states' perspective, they are not commercial transactions but investment instruments, allowing states to finance their fundamental public needs.

The adoption of the Fedax test allows one to distinguish sovereign bonds involving fundamental public interests, such as economic growth, budgetary purposes, adequate capital and liquidity or stability of financial system, from bonds issued for the other, non-legitimate purposes, such as financing armed conflicts or excessive armaments.

Applying the Fedax test to the Ambiente Ufficio case, an arbitral tribunal could have argued that the issuance of sovereign bonds by Argentina served its budgetary needs and was a plausible way to secure its financial stability. By acquiring bonds and security entitlements, its holders contributed to this aim and therefore invested in Argentina.

76 But see: M. Waibel, Opening Pandora's Box: Sovereign Bonds in International Arbitration, op. cit., at p. 721, arguing that almost every legitimate governmental transaction satisfies the Fedax test.

77 See point 3.1.2.3. below. 


\subsubsection{The relevance of the Salini criteria}

a) Legal basis for the rejection of the Salini criteria

The Abaclat and the Ambiente Ufficio tribunals rejected the Salini criteria as jurisdictional requirements of the ICSID jurisdiction ${ }^{78}$. The Abaclat tribunal abandoned the Salini criteria simply because the result of their adoption would be contrary to the interpretative result it wanted to reach. The tribunal stated that application of the Salini criteria would mean 'that Claimants' contributions would not be given the procedural protection afforded by the ICSID Convention"79. In other words, the tribunal concluded that the value of the claimants' contribution constituted an investment which deserved protection under the ICSID Convention, independently of the Salini criteria ${ }^{80}$. Additionally, the Abaclat tribunal held that the Salini criteria were never included in the ICSID Convention and that they are controversial and applied by tribunals in different manners and to varying degrees ${ }^{81}$. Similarly, the Ambiente Ufficio

78 Ambiente Ufficio S.p.A. and others v. the Argentine Republic, Decision on jurisdiction and admissibility, supra, at para 479: “...the present Tribunal endorses the view that the term "investment" in Art. 25(1) of the ICSID Convention should not be subjected to an unduly restrictive interpretation. Hence, the Salini criteria, if useful at all, must not be conceived of as expressing jurisdictional requirements stricto sensu". See also Abaclat and others $v$. the Argentine Republic, Decision on jurisdiction and admissibility, supra, at para 363.

79 Abaclat and others v. the Argentine Republic, Decision on jurisdiction and admissibility, supra, at para 364.

80 Ibidem: "In other words - and from the value perspective - there would be an investment, which Argentina and Italy wanted to protect and to submit to ICSID arbitration, but it could not be given any protection because - from the perspective of the contribution - the investment does not meet certain criteria". It does not appear to be a proper conclusion since the sole economic value of the contribution does not amount to investment (see point 3.1.2.2. (a) above.).

81 Abaclat and others $v$. the Argentine Republic, Decision on jurisdiction and admissibility, supra, at para 364. Some arbitral tribunals introduced additional criteria to the Salini list, for example in Phoenix v. Czech Republic Award the tribunal added the criteria that assets be invested in accordance with the laws of the host State and that they be invested in good faith (Phoenix Action Ltd. v. The Czech Republic, Award of 15.4.2009, ICSID Case no ARB/06/5, at para 114) whereas in Joy Mining v. Egypt the tribunal added the regularity of profit and return criterion (Joy Mining Machinery Limited 
tribunal dispensed from the jurisdictional test based on the Salini criteria, emphasizing that the term "investment" in the ICSID Convention should not be subject to an unduly restrictive interpretation ${ }^{82}$.

Both tribunals found that the Salini criteria should serve rather as a description of the characteristics that each investment may have and not as a limit to the ICSID jurisdiction ${ }^{83}$. In this respect, they followed the view of Professor Christoph Schreuer, as expressed in his Commentary to the ICSID Convention of $2001^{84}$. This approach can be described as a "typical characteristic" approach - the term proposed by the sole arbitrator Michael Hwang in the MHS v. Malaysia award on jurisdiction of $17.5 .2004^{85}$. According to this view, a typical investment can be characterized with the use of several hallmarks ${ }^{86}$. They are not prerequisites for the existence of an investment and they cannot be treated by ICSID tribunals as jurisdictional requirements. Indeed, these hallmarks constitute merely a descriptive list of the characteristics of an investment. As Professor Christoph Schreuer has remarked:

v. The Arab Republic of Egypt, Award on jurisdiction, supra, at para 53). Other tribunals dispensed from the economic development criterion (Consorzio Groupement L.E.S.I. DIPENTA v. People's Democratic Republic of Algeria, Award of 10.1.2005, ICSID Case no $\mathrm{ARB} / 03 / 8$, at para 13). No unanimous approach to the legal character of these criteria has been developed so far. On divergent views of tribunals on the number and legal the character of the Salini criteria see Mr. Saba Fakes v. Republic of Turkey, Award, supra, at para 97-105.

82 See FN 78.

83 Abaclat and others v. the Argentine Republic, Decision on jurisdiction and admissibility, supra, at para 364: "The Salini criteria may be useful to further describe what characteristics contributions may or should have". Ambiente Ufficio S.p.A. and others v. the Argentine Republic, Decision on jurisdiction and admissibility, supra, at para 481: "the Salini test, while not constituting mandatory prerequisites for the jurisdiction of the Centre in the meaning of Art. 25 of the ICSID Convention, may still prove useful, provided that they are treated as guidelines and that they are applied in conjunction and in a flexible manner".

84 Ch. H. Schreuer, The ICSID Convention: A Commentary, Cambridge University Press, Cambridge 2001, p. 1, at p. 140: “These features should not necessarily be understood as jurisdictional requirements but merely as typical characteristics of investments under the Convention."

85 Malaysian Historical Salvors SDN BHD v. Malaysia, Award on jurisdiction of 17.5.2007, supra, at para 44 and 70.

86 Ibidem, at para 72. 
The development in practice from a descriptive list of typical features towards a set of mandatory legal requirements is unfortunate. The First Edition of this Commentary cannot serve as authority for this development. To the extent that the "Salini test" is applied to determine the existence of an investment, its criteria should not be seen as distinct jurisdictional requirements each of which must be met separately ${ }^{87}$.

It appears that the Salini criteria serve as a useful tool in describing the typical characteristics of a foreign direct investment ("FDI"). They reflect the nature of a FDI as a long-lasting presence of an investor in the host country (a contribution) which often takes the form of an enterprise or other project. However, the ICSID Convention also protects indirect investments. It would be misleading to apply the same terminology and the same set of criteria to assess the character of a FDI and indirect investments. In case of indirect investments, it is not the contribution which plays the major role in characterizing an investment. Financial investments can be described from the perspective of proprietary rights, rather than a long-lasting contribution in the host country. As Professor Thomas W. Wälde has stated:

Scholars and practitioners familiar with the 1970s discussion on "foreign direct investment" will be influenced by (...) definitions of foreign direct investment which require a lasting commitment of capital in a project owned and controlled from abroad that is intended to generate revenues from its operation over an extended period. However that definition is no longer used in most modern investment treaties. These definitions commonly describe "investment" rather as a proprietary right ${ }^{88}$.

This approach to the new categories of investments serves as a basis for rejection of the Salini criteria. The Salini criteria cannot properly describe the character of such proprietary rights as intellectual property rights or financial obligations.

87 Ch. H. Schreuer, L. Malintoppi, A. Reinisch, A. Sinclair, The ICSID Convention: A Commentary, Cambridge University Press, Cambridge 2009, p. 1, at p. 133. See also: Ambiente Ufficio S.p.A. and others v. Argentine Republic, Decision on jurisdiction and admissibility, supra, at para 480 .

88 T. W. Wälde, The Serbian Loans Case: A Precedent for Investment Treaty Protection of Foreign Debt?, op. cit., at p. 404. 
In light of the above, the Abaclat and Ambiente Ufficio tribunals properly concluded that the ICSID Convention does not impose the requirement to fulfil the criteria of the existence of an investment ${ }^{89}$. The Salini criteria should serve merely as an indicative list of the characteristics of an investment and not as jurisdictional requirements for ICSID arbitration. The strict adoption of the Salini criteria could lead to unacceptable consequences, such as exclusion from the ambit of the ICSID Convention of transactions that are commonly regarded as investments simply because they fail to (or insufficiently) fulfil one of the Salini criteria.

a) Qualification of sovereign bonds as investments under the Salini criteria

Although both tribunals recognized the usefulness of the Salini criteria as typical characteristics of an investment, only the Ambiente Ufficio tribunal applied them by the analysis of the legal character of sovereign bonds and security entitlements under the ICSID Convention ${ }^{90}$. Applying the "overall operation" principle ${ }^{91}$, the Ambiente Ufficio tribunal assessed the character of the Salini criteria from the perspective of the whole bonds issuance process and not particular bonds or security entitlements. Such a method of interpretation may be of general significance for all financial instruments issued by states, even though the application of the "overall operation" principle appears unfounded on the facts of this particular case ${ }^{92}$.

The Salini criteria aim to protect states' interests from an uncontrolled increase in arbitral proceedings initiated by private individuals. For

89 On the limited usefulness of the Salini criteria see: M. Sasson, Substantive Law in Investment Treaty Arbitration, Kluwer Law International, The Hague 2010, p. 1, at p. 35: "In short, these five characteristics are of limited usefulness in the identification of 'investment'. They are so elastic and subjective that a determined interpreter can stretch them to serve virtually any purpose. In any event, these characteristics should not be treated as self-sufficient for the designation of 'investment' ".

90 Ambiente Ufficio S.p.A. and others v. Argentine Republic, Decision on jurisdiction and admissibility, supra, at para 479, para 482-487.

91 See point 3.1.1.2. above.

92 See ibidem. 
this reason, it appears plausible to analyze the Salini criteria from the perspective of states, rather than investors, and to assess them globally within particular emissions. Sovereign bonds are issued in series entailing hundreds or thousands of bonds having the same principal amounts, bond yields and maturity dates. Packages of bonds from the same series are purchased on the primary market by financial institutions such as banks, which distribute them amongst individual investors. The homogeneity of particular bonds within one series allows states to treat their issuance as one transaction. Consequently, the character of sovereign bonds should not be assessed from the perspective of a singular bond instrument and singular purchase transaction but, rather, from the perspective of the whole issuance process, as rightly pointed out by the Ambiente Ufficio tribunal $^{93}$. Hence, it appears that the bonds issuance process meets the Salini criterion of contribution, since it enables states to collect millions of dollars by virtue of a single transaction.

One can argue that, from the investors' point of view, there are thousands of contracts concluded with the state by individual bondholders and that each of these contracts should be assessed separately. Yet bondholders' rights are in each case virtually the same. Within one series of bonds there are the same conditions for repayment, principal amounts, bond yields, maturity dates and dispute settlement provisions. Nothing prevents an arbitral tribunal from concluding that the bond issuance process constitutes one investment and that each individual bondholder holds a proportional part of this investment. Such conclusion should not impair investors' rights to seek compensation from states independently from other investors.

According to this view, an investment can exist despite changes in the personal details of particular investors. From the state's perspective, when easily tradable bonds frequently change ownership on the secondary market, there still exists one and the same investment evidenced by such bonds. However, according to Professor Zachary Douglas, following

93 Ambiente Ufficio S.p.A. and others v. Argentine Republic, Decision on jurisdiction and admissibility, supra, at para 483: "As regards, first, the prerequisite of a substantial contribution on the part of the investor, it is not relevant that the contribution of the single Claimant might have been minor. What counts is that the bonds issued as a whole amounted, without doubt, to a substantial contribution on the investors' part". 
a change of ownership, there exists insufficient transparency of a financial instrument and such an instrument cannot receive protection as an investment:

The nexus between the funds transferred as consideration for the negotiable instrument and the employment of such funds for an investment purpose in the host state requires a certain degree of transparency in the transaction that invariably will only be present as between the issuer and the first holder ${ }^{94}$

Nevertheless, when assessing the transparency of a financial instrument, not only economic, but also the legal characteristics of this instrument should be taken into account. Subsequent bondholders are bound by the contractual position of the first bondholder, including the right to repayment. Upon a change of ownership, the nexus between economic contribution and corresponding rights remains visible, even when this contribution has already been used by the host state for an investment purpose.

The possible weak point of the presented view relates to the problem of treaty rights applicable to particular sovereign bondholders. Despite the homogeneity of bonds issued within the same series, each of these bonds may be held by investors from different states and may thus be subject to protection afforded by different investment treaties. Moreover, subsequent changes of bondholders may lead to treaty shopping. Investors could seek a better price for their investments by selling them to entities located in a state with better treaty protection, such as vulture funds. A possible solution to this problem would be the application of the continuous nationality principle. Following the date of the alleged breach of treaty obligations, investors would be unable to sell their investment abroad to obtain better treaty protection, since this would mean transferring more treaty rights that they actually possess ${ }^{95}$.

94 Z. Douglas, The International Law of Investment Claims, op. cit., at p. 181.

95 The continuous nationality principle is based on the nemo dat quod non habet or nemo potiorem potest transferre quam ipse habet principle. As Professor Zachary Douglas observed: "an individual or entity with legal or beneficial ownership of investment at the time of the alleged injury to the investment cannot transfer better rights in respect of that investment than it had at that time", Z. Douglas, The International Law of Investment 
Application of the presented view allows fulfilment of the duration requirement laid down in the Salini test, despite frequent changes in the ownership of particular bonds. Such changes do not influence the duration of the whole investment, which is specified in the bond issuance documents and ends with the maturity date of the whole series of bonds. Most frequently, this time is set as a period of several years.

Changes in the identity of bondholders do not differ significantly from changes of ownership in respect of FDIs, where an investor may acquire an investment, for instance, by purchasing shares in a mining company or purchasing a contract for construction of a highway. In such situations, the physical presence of an investment in a host country continues despite personal changes in the identity of individual investors. A similar situation occurs with regard to sovereign bonds. The only difference is the ease and frequency of changes in the identities of bondholders.

As regards both FDIs and sovereign bonds, all personal changes relate to the subject of the investment (i.e. the investor) and not to the object of investment (i.e. the investment itself). Therefore, such changes do not preclude fulfilment of the Salini duration requirement. The only requirement for an investor is that it should hold an investment at the date of the alleged breach of investment treaty obligations ${ }^{96}$. A similar view was expressed by the Ambiente Ufficio tribunal, according to which "it is the duration of bonds that is relevant" 97 and not the amount of time for which particular bonds are held by their holders.

As far as the risk-sharing criterion is concerned, sovereign bondholders share not only commercial risk but also investment risk with the state. They face the same risk of non-payment as in the case of commercial transactions with government entities. Yet, additionally, they are subject to the risk of state insolvency and they may be involved in a sovereign debt restructuring process. This is not a commercial risk,

Claims, op. cit., at p. 461. See also T. W. Wälde, The Serbian Loans Case: A Precedent for Investment Treaty Protection of Foreign Debt?, op. cit., at p. 405: "Examples from other investment treaty-cases suggest that there is a requirement of "continuous nationality" between, at least, the time of the breach (...) until the time that the claim is launched".

96 Z. Douglas, The International Law of Investment Claims, op. cit. at pp. 290-297.

97 Ambiente Ufficio S.p.A. and others v. the Argentine Republic, Decision on jurisdiction and admissibility, supra, at para 484. 
since bondholders may be expropriated and their rights to be repaid may be denied by virtue of a decision of the sovereign state ${ }^{98}$. This is a more unpredictable risk than commercial risks associated with transactions entered into with commercial undertakings ${ }^{99}$. There are also fewer possibilities to protect bondholders from such risk, since they have no influence on the host state law and policy and they are unable to predict future state decisions. They can only use various contractual tools, such as credit default swaps, to protect themselves from this risk ${ }^{100}$.

The fourth Salini criterion, contribution to the state development, is also fulfilled in the case of sovereign bonds. As stated above, sovereign bonds involve the fundamental public interest and they profoundly impact upon the entire state economy, enabling a state to maintain its financial stability. It is impossible to develop the state economy without access to financial markets and without the opportunity to quickly and cheaply acquire funds on these markets. However, the Ambiente Ufficio tribunal's finding that the sole volume of the bonds involvement demonstrates the contribution to the state's economic development, proves inadequate in this respect ${ }^{101}$.

With regard to the possible additional criteria, sovereign bonds fulfil the criterion of the regularity of profit and return. Bondholders' yields

98 See ibidem, at para 485: "However, given the risk of the host State's sovereign intervention, a risk that became manifest in Argentina's very default and restructuring, what is at stake is not an ordinary commercial risk".

99 Low level of protection of sovereign bondholders causes insecurities on the markets and states feel the negative impact, especially with increasing bond yields. See: Ch. Hofmann, Greek Debt Restructuring and Abaclat v. Argentina - The impact of Bilateral Investment Treaties (BITs) on the Greek default, "Transnational Notes. Reflections on Transnational Litigation and Commercial Law”, 3.10.2012, available at: http://blogs.law. nyu.edu/transnational/2012/10/greek-debt-restructuring-and-abaclat-v-argentina-theimpact-of-bilateral-investment-treaties-bits-on-the-greek-default/.

100 Credit default swap („CDS”) is a contract providing insurance against a default by a sovereign entity. The buyer of CDS makes periodic payments to the seller and in return obtains a right to sell a bond for its face value in case of a state's default. See: J. Hull, M. Predescu, A. White, The Relationship Between Credit Default Swap Spreads, Bond Yields, and Credit Rating Announcements, Joseph L. Rotman School of Management University of Toronto, Toronto 2004, available at: http://www.einstitutional.com/geodesicweb/papers/ Hull_Predescu_White.pdf.

101 Ambiente Ufficio S.p.A. and others v. the Argentine Republic, Decision on jurisdiction and admissibility, supra, at para 487. 
are specified in bonds issuance documents and they are fixed and paid on the bonds maturity date ${ }^{102}$. Therefore, investors are assured that they will receive regular profit from their investments.

In conclusion, sovereign bonds meet at least some of the Salini criteria ${ }^{103}$. Whilst fulfilment of the contribution and duration criteria requires that bonds be qualified as constituting part of a bigger economic operation, which may give rise to several controversies, fulfilment of the remaining criteria appears to be relatively unproblematic to establish. The Ambiente Ufficio tribunal's conclusion in this respect deserves apprehension $^{104}$.

\subsubsection{Conclusion}

Neither the Abaclat nor the Ambiente Ufficio tribunal fully addressed the economic contribution aspect of an investment and its division from single commercial transactions. Only the Ambiente Ufficio tribunal elaborated on the Salini criteria as being typical characteristics of an investment. Neither of the tribunals differentiated between sovereign bonds and security entitlements. Consequently, their qualification of the claimants' security entitlements as investments under the ICSID Convention appears to be poorly grounded. Yet, despite these deficiencies, the decisions in question may serve as useful guidance for ICSID arbitral tribunals dealing with sovereign bond claims. It stems from the above considerations that many arguments may exist for qualifying sovereign bonds as investments under the ICSID Convention, especially by applying the Salini criteria.

102 Ibidem, at para 486: "the bonds and security entitlements have to be deemed a single economic operation, with the interest supposed to be paid periodically satisfying the criterion of regularity of profits and returns".

103 Against the qualification of sovereign bonds as investments on the grounds of the Salini criteria see: M. Waibel, Opening Pandora's Box: Sovereign Bonds in International Arbitration, op. cit., at pp. 722-729. See especially ibidem, p. 722: "Sovereign bonds do not display typical features of an investment. They are ordinary commercial transactions outside ICSID's objective jurisdictional core".

104 Ambiente Ufficio S.p.A. and others v. the Argentine Republic, Decision on jurisdiction and admissibility, supra, at para 482: “...in the Tribunal's view, the bonds/security entitlements which are at stake in the present proceedings fulfil the criteria generally ascribed to the Salini test". 


\subsubsection{The BIT definition of an investment}

During the Abaclat and Ambiente Ufficio proceedings, two major problems arose in relation to the BIT's definition of an investment; namely whether or not the claimants' security entitlements fell within the scope of the definition of an investment contained in Article 1 (c) and whether or not they met the territorial link requirement of the Argentina-Italy BIT.

\subsubsection{Qualification of security entitlements as investments under the Argentina-Italy BIT}

The typical formulation found in BITs defines an investment in broad terms as "every kind of asset"105. This non-exhaustive list of assets covers not only FDI but also various kinds of indirect investments, including loans and other financial instruments ${ }^{106}$. The Argentina-Italy BIT is no exception to this rule; Article 1 (c) thereof pertains to: "bonds, private and public financial instruments or any other right to performances or services having economic value, including capitalized revenues".

The Argentina-Italy BIT's wording is wide enough to encompass such financial instruments as sovereign bonds ${ }^{107}$. In light of the fact that the Abaclat and Ambiente Ufficio tribunals virtually equated sovereign

105 C. Yannaca-Small, L. Liberti, International Investment Law: Understanding Concepts and Tracking Innovations, Chapter 1, Definition of Investor and Investment in International Investment Agreements, Organization for Economic Co-operation and Development (OECD) 2008, p. 1, at p. 9: "There is no single definition of what constitutes foreign investment. International investment agreements usually define investment in very broad terms. They refer to "every kind of asset" followed by an illustrative but usually non-exhaustive list of assets, recognising that investment forms are constantly evolving", available at: http://www.oecd.org/daf/inv/internationalinvestmentagreements/40471468. pdf.

106 T. W. Wälde, The Serbian Loans Case: A Precedent for Investment Treaty Protection of Foreign Debt?, op. cit., at p. 386: "In many, if not most of such modern treaties, loans and similar financial instruments are covered by the broad notion of 'investment'. This modern notion of protected investment is much wider than the earlier version of "foreign direct investment", which required a lasting commitment of capital to a productive project owned or controlled by the investor".

107 G. Abi-Saab, Abaclat and Others v. Argentina, Decision on Jurisdiction and Admissibility, Dissenting Opinion, supra, at para 68: "On this question I agree with the majority analysis that Article $1 / 1 /$ c covers financial instruments, and that its language is large enough to encompass security entitlements in the Argentinean bonds". 
bonds with security entitlements, it is unsurprising that they held that the claimants' security entitlements qualified as investments within the BIT definition. In their analysis, they focused solely on the aspect of contribution (the Abaclat tribunal $)^{108}$ and the economic value they represented (the Ambiente Ufficio tribunal) ${ }^{109}$. Nevertheless, they failed to address the legal and factual remoteness of the security entitlements from Argentina's issuance of bonds ${ }^{110}$.

\subsubsection{The territorial link requirement}

The ICSID Convention does not impose a requirement that an investment must be undertaken within the territory of the host state. However, several BITs contain a territorial link requirement when defining an investment ${ }^{111}$. The aim of such provisions is to restrict the scope of protected investments and to establish a strong nexus with the host state territory. The Argentina-Italy BIT includes a territorial link requirement in Article $1^{112}$ as a general condition for establishing all kinds of investment. This requirement refers to investments enumerated in the non-exhaustive list of investments contained in Article 1 (i.e. prima facie also to bonds and financial instruments, which are included in point c) of this list).

In the Abaclat and Ambiente Ufficio proceedings, Argentina contended that the acquisition of security entitlements by the claimants was not accompanied by any physical transfer of funds into the territory of Argentina and, thus, the necessary territorial link requirement was

108 Abaclat and others v. the Argentine Republic, Decision on jurisdiction and admissibility, supra, at para 371.

109 Ambiente Ufficio S.p.A. and others v. the Argentine Republic, Decision on jurisdiction and admissibility, supra, at para 482-483.

110 See point 3.1.1.1. above.

111 See: Article 1 (g) Canada-Romania BIT: “investment' means any kind of asset owned or controlled either directly, or indirectly through an investor of a third state, by an investor of one Contracting Party in the territory of the other Contracting Party"; Article 1 (a) Poland-China BIT: "The term 'investments' means every kind of asset made as investment in accordance with the laws and regulations of the Contracting Party accepting the investment in its territory".

112 Article 1 Argentina-Italy BIT: “'Investment' shall mean (...) any conferment or asset invested or reinvested by an individual or corporation of one Contracting Party in the territory of the other Contracting Party...". 
absent ${ }^{113}$. Both tribunals rejected this objection, emphasizing that no physical transfer of funds to the territory of Argentina was necessary ${ }^{114}$. The tribunals' decisions touched upon the controversy of how to apply the territoriality requirement to financial instruments. Divergent views on this issue are presented ${ }^{115}$.

a) The criterion of the state's benefits from an investment

In the view of the Abaclat and Ambiente Ufficio tribunals, when dealing with financial instruments the relevant criterion should be the manner in which host state benefited from an investment ${ }^{116}$. The tribunals ruled that Argentina benefited from the issuance of security entitlements ${ }^{117}$. They followed the line of reasoning established in the Fedax decision on jurisdiction, where the arbitral tribunal stated that:

While it is true that in some kinds of investments (...) such as the acquisition of interests in immovable property, companies and the like, a transfer of funds or value will be made into the territory of the host country, this does not necessarily happen in a number of other types of investments, particularly those of a financial nature. It is a standard feature of many international financial transactions that the funds involved are not physically transferred to the territory of the beneficiary, but put at its disposal elsewhere. In fact, many loans and credits do not leave

113 Abaclat and others v. the Argentine Republic, Decision on jurisdiction and admissibility, supra, at para 341 (ii).

114 See FN 116.

115 Ch. H. Schreuer, L. Malintoppi, A. Reinisch, A. Sinclair, The ICSID Convention: A Commentary, op. cit., at pp. 139-140; Z. Douglas, The International Law of Investment Claims, op. cit., at pp. 171-172.

116 As held the Abaclat tribunal, the determinative factor is 'for the benefit of whom the funds were ultimately used, and not the place where the funds were paid out or transferred", see: Abaclat and others v. the Argentine Republic, Decision on jurisdiction and admissibility, supra, at para 374. See also: Ambiente Ufficio S.p.A. and others v. the Argentine Republic, Decision on jurisdiction and admissibility, supra, at para 499: "The Tribunal is convinced that, in order to identify in which State's territory an investment was made, one has to determine first which State benefits from this investment".

117 Abaclat and others $v$. the Argentine Republic, Decision on jurisdiction and admissibility, supra, at para 374; Ambiente Ufficio S.p.A. and others v. the Argentine Republic, Decision on jurisdiction and admissibility, supra, at para 500. 
the country of origin at all, but are made available to suppliers or other entities. (...) The important question is whether the funds made available are utilized by the beneficiary of the credit (...) so as to finance its various governmental needs ${ }^{118}$.

A similar view was adopted by the Inmaris Perestroika tribunal, which concluded:

In the Tribunal's view, an investment may be made in the territory of a host State without a direct transfer of funds there, particularly if the transaction accrues to the benefit of the State itself. Here, the benefits of Claimants' investments, considered as an integrated whole, were received by Respondent ${ }^{119}$.

By placing excessive emphasis on the benefits derived from an investment, the Abaclat, Ambiente Ufficio, Fedax and Inmaris tribunals dealt rather with the contribution aspect of financial investments, leaving aside their character as proprietary rights. This approach disregards the fact that financial investments sometimes do not bring direct economic benefits to the host state. Moreover, the tribunals concentrated on the benefits flowing from an investment and not on the investment itself. Finally, the above propositions allow investments to be linked with the host state itself, as opposed to its territory ${ }^{120}$.

b) The criterion of the location of a debtor

The other proposal, put forward by Professor Christoph Schreuer, emphasizes the location of the debtor, i.e. the host state, as a decisive

118 Fedax N.V. v. the Republic of Venezuela, Decision of the Tribunal on Objections to Jurisdiction, supra, at para 41.

119 Inmaris Perestroika Sailing Maritime Services $\mathrm{GmbH}$ and others v. Ukraine, Decision on jurisdiction of 8.03.2010, ICSID Case no ARB/08/8, at para 124.

120 This was highlighted by Professor Georges Abi-Saab in his dissenting opinion to the Abaclat decision: "It is noteworthy in this respect that the section under which this question is addressed in the majority award is entitled „Made in Argentina” (...) and not "Made in the territory of Argentina" (...), an omission symptomatic of the resultoriented style of the whole award" (G. Abi-Saab, Abaclat and Others v. Argentina, Decision on Jurisdiction and Admissibility, Dissenting Opinion, supra, at para 88). See also: Abaclat and others $v$. the Argentine Republic, Decision on jurisdiction and admissibility, supra, at para 372. 
factor in establishing a nexus with the host state territory. According to Professor Schreuer:

Investment in movable and particularly immovable property will require a territorial nexus. In cases involving financial obligations the locus of the investment can often be determined by reference to the debtor and its location. In this way financial instruments issued by States have their situs in that State ${ }^{121}$.

However, this argumentation also seems unpersuasive. It leads to the conclusion that all foreign investments fulfil the territorial link requirement, since all of them take place between a foreign investor and a host state. By virtue of such argumentation, it would be impossible not to fulfil the territorial link requirement. Moreover, as in the Abaclat, Ambiente Ufficio, Fedax and Inmaris decisions, Professor Schreuer's proposal allows a nexus to be established with the host state itself, rather than with its territory ${ }^{122}$.

c) The criterion of a link with a specific enterprise or project in the host state's territory

An alternative view was proposed by Professor Georges Abi-Saab in his Dissenting Opinion in the Abaclat decision. He concluded that the fact that an investment has been undertaken in the territory of the host country can be demonstrated by tracing it to a specific project, entity or activity in the territory of this country ${ }^{123}$.

It is submitted that this argumentation is built on false assumptions. First of all, the territorial link requirement in BITs is clearly distinguishable from the requirement for a connection with a specific project or enterprise. There are BITs that impose a requirement for financial investments, such as bonds, to be linked with companies or other enterprises, but they

121 Ch.H. Schreuer, L. Malintoppi, A. Reinisch, A. Sinclair, The ICSID Convention: A Commentary, op. cit., at p. 140.

122 See FN 120.

123 G. Abi-Saab, Abaclat and Others v. Argentina, Decision on Jurisdiction and Admissibility, Dissenting Opinion, supra, at para 93. 
dispense with the territorial link requirement ${ }^{124}$. Moreover, there are BITs that impose both a territorial link requirement and a requirement for financial investments to be linked with enterprises ${ }^{125}$. Finally, some BITs include a territorial link requirement but do not require that financial investments be linked with a specific project or enterprise. One such example is Article 1 of the Argentina-Italy BIT, which was analysed by the Abaclat and Ambiente Ufficio tribunals ${ }^{126}$.

It appears that, on the basis of BITs, the territorial link requirement cannot be subsumed within the requirement for a link with a project, entity or activity in the territory of the host state. The requirement for such a link does not constitute an inherent element of the BIT definition of an investment. Only some BITs impose such a requirement and it is obviously incorrect to ascribe such characteristics to all financial investments under all BITs. This would mean that financial instruments cannot exist per se, without a strict connection with a foreign direct investment. Such an assumption lacks any legal basis. Neither the ICSID Convention nor the majority of BITs impose a requirement that financial investments be linked to enterprises or other direct investments in the host state.

d) The private international law criterion

The final proposition entails the necessity to introduce legal criteria for determining the situs of a debt, in order to establish a territorial link with the host state. As Professor Zachary Douglas has stated:

124 For example, Article 1 (1) of the Bulgaria-Netherlands BIT states as follows: “The term 'investment' means every kind of asset and more particularly, though not exclusively: (b) rights derived from shares, stocks, bonds and other kinds of interests in companies and joint ventures; c) claims to money, to other assets or to any performance having an economic value with regard to the investment".

125 See Article 1 (a) (ii) Netherlands-Romania BIT, which provides that: "the term 'investments' means every kind of asset invested by investors of one Contracting Party in the territory of the other Contracting Party in conformity with the laws and regulations of the latter, and more particularly, though not exclusively: (...) (ii) rights derived from shares, bonds and other kinds of interests in companies and joint ventures".

126 See FN 112. 
Localising something that is intangible is a more complex problem. Resort must be had to the rules of private international law of the host state which, in respect of some forms of intangible property, may supply a fictitious situs. A debt may have its situs at the place of domicile of the debtor. (...) In each case, if the host state's rules of private international law locate the intangible property rights in the host state, then the territorial requirement is satisfied with respect to a putative investment in that form of intangible property ${ }^{127}$.

However, this view allows a connection to established between a debt and the jurisdiction and law of the host state, as opposed to its territory. The aim of private international law differs from that of the territorial link requirement in BITs. Such private international law criteria as the currency of payment or forum selection clauses do not pertain to a specific territory ${ }^{128}$. Only the place of payment criterion could possibly serve as a guideline to establish a territorial link with the host state. However, in the case of financial investments, it is usually impossible to ascertain the exact place of payment, especially in relation to non-cash payments.

Furthermore, BITs provide no recourse to private international law for their parties. There is no reason why national private international law should influence the scope of investments protected under BITs, despite the silence of BITs in this regard. Additionally, there is no reason why the private international law of the host state, and not the law of the investor's state, should be decisive in this respect. Granting such a power to the host state could lead to considerable modifications of its obligations under the BIT. Host states would be entitled to unilaterally narrow the scope of protected investments by prescribing the relevant rules of their private international laws.

e) Inapplicability of the territorial link requirement to financial instruments

127 Z. Douglas, The International Law of Investment Claims, op. cit., at pp. 171-172.

128 G. Abi-Saab, Abaclat and Others v. Argentina, Decision on Jurisdiction and Admissibility, Dissenting Opinion, supra, at para 82-83. 
Consequently, none of the above interpretative proposals allows the territorial dimension of financial instruments such as sovereign bonds and security entitlements to be addressed. It is clear that financial instruments do not possess all of the characteristics of foreign direct investments. They often do not entail a transfer of funds into the territory of the host state. As Professor Christoph Schreuer has remarked:

Not all investment activities are physically located on the host State. This is particularly true of financial instruments (...). If a treaty includes loans and claims to money in its definition of investment, it would be unrealistic to require a physical presence in or a transfer of funds into the host State ${ }^{129}$.

It is hardly possible to imagine how the territorial link requirement may be fulfilled in the case of financial instruments. Should they be purchased by an investor directly in the territory of the host state (with the investor having a physical presence in this territory) or would it suffice for them to be purchased by an institution having its seat in the host state territory? Would it be necessary to physically transfer the purchase price to the host state or would it be required to be paid to a financial institution having its seat in the host state?

It stems from the above considerations that such speculations are futile. In the realm of modern international financial relations, it is impossible to fulfil the territorial link requirement. Widespread non-cash payments have become the major avenue for accomplishing financial transactions between individuals, private corporations and public entities. They do not entail any physical transfer of funds and they are often carried out by multinational banks and financial institutions. No link with any particular state's territory can be established.

It appears that the territorial link requirement found in BITs is illsuited to the new categories of investments, such as indirect investments. This is the case not only in respect of financial instruments. The same applies to intellectual property rights. It is difficult to imagine how intellectual property rights could be invested in the territory of the host

129 Ch. H. Schreuer, L. Malintoppi, A. Reinisch, A. Sinclair, The ICSID Convention: A Commentary, op. cit., at pp. 139-140. 
state. This is especially true of rights protecting immaterial works of arts, such as computer programs.

As regards indirect investments, each connecting factor capable of being imagined seems artificial. Its adoption disregards the major fact that indirect investments often take form of intangible property. It is impossible to establish a material, physical link between such property and the specific territory. Accordingly, the territorial link requirement contained in several BITs refers only to FDIs. The only tenable conclusion is to dispense with this requirement in the case of indirect investments, such as financial instruments.

In conclusion, the territorial link requirement contained in BITs does not pertain to sovereign bonds and security entitlements. It would be impossible to ascertain the exact scope thereof with respect to such kinds of investments. Therefore, the Abaclat and Ambiente Ufficio tribunals should have completely dispensed with this requirement, instead of relying on the potential benefits to the Argentinian economy from the claimants' security entitlements ${ }^{130}$.

\subsection{Treaty character of the claims arising from sovereign bonds and security entitlements}

When qualifying financial instruments as investments, an important question to be answered is whether or not states may expropriate such investments or whether all state action in this respect should be treated merely as contractual defaults. The latter conclusion would considerably narrow the scope of treaty protection of such investments.

The issue of taking property is closely interrelated with the scope of the definition of a foreign investment ${ }^{131}$. In the case of financial investments, it is often very difficult to grasp the difference between

130 See: CSOB v. The Slovak Republic, Decision of the Tribunal on Objections to Jurisdiction, supra, at para 78: "The Tribunal notes, in this connection, that while it is undisputed that CSOB's loan did not cause any funds to be moved or transferred from CSOB to the Slovak Collection Company in the territory of the Slovak Republic, a transaction can qualify as an investment even in the absence of a physical transfer of funds".

131 UNCTAD, Taking of property, "UNCTAD Series on issues in international investment agreements”, New York and Geneva 2000, p. 1, at p. 36. A. Reinish, Expropriation, [in:] 
an ordinary breach of contract and indirect expropriation. It should be emphasized that a mere breach of contract, such as non-payment of a debt, does not suffice to successfully claim that expropriation has occurred. In the NAFTA Waste Management case, the arbitral tribunal held that: „an enterprise is not expropriated just because its debts are not paid or other contractual obligations towards it are breached"132. In the tribunal's view, the non-performance of contractual obligations must be accompanied by "other elements" 133 , such as an "outright repudiation" of rights, in order to qualify as expropriation ${ }^{134}$. This line of interpretation was confirmed in the SGS v. Philippines case, where the arbitral tribunal stated: "A mere refusal to pay a debt is not an expropriation of property, at least when remedies exist in respect of such a refusal"135. Hence, there must be an additional element in the state's conduct, going beyond the standard conduct of a contracting party. As the ICSID tribunal in the Impregilo case stated: "in order that the alleged breach of contract may constitute a violation of the BIT, it must be the result of behaviour going beyond that which an ordinary contracting party could adopt" ${ }^{\prime 36}$.

In light of such jurisprudence, the question arises as to whether or not it is possible for a state to expropriate indirect investments such as sovereign bonds. It seems that an extraordinary level of misconduct towards investors is required, going beyond the scope of ordinary breaches of contracts ${ }^{137}$.

P. Muchlinski, F. Ortino, Ch. Schreuer (ed.), 'The Oxford Handbook on International Investment Law', Oxford University Press, New York 2008, p. 407, at p. 410.

132 Waste Management, Inc. v. United Mexican States, Award of 30.4.2004, ARB(AF)/00/3, at para 160.

133 Ibidem, at para 174.

134 A. Reinish, Expropriation, op. cit., at p. 419.

135 SGS Société Générale de Surveillance S.A. v. Republic of the Philippines, Decision of the tribunal on objections to jurisdiction of 29.1.2004, ICSID Case no ARB/02/6, at para 161; A. Reinish, Expropriation, op. cit., at p. 419.

136 Impregilo SpA v. the Islamic Republic of Pakistan, Decision on jurisdiction of 22.4.2005, ICSID case no ARB/03/3, at para 260, A. Reinish, Expropriation, op. cit., at p. 420 .

137 As Professor Thomas Wälde observed: "In contemporary circumstances, outright expropriation as explicit repudiation and cancellation of debt is rare" (T. W. Wälde, The Serbian Loans Case: A Precedent for Investment Treaty Protection of Foreign Debt?, op. cit., at p. 409). 
Assessing the character of the Argentinian exchange offer, the Abaclat tribunal specified four elements distinguishing Argentina's actions from an ordinary breach of contract. These were: (1) a unilateral modification of payment obligations, (2) without invoking any contractual or treaty provisions excusing its non-performance, (3) intervention as a sovereign, (4) modification of payment obligations towards creditors in general ${ }^{138}$. The first two elements do not constitute distinguishing factors, since they are also present in ordinary breaches of contracts. As far as the following two elements are concerned, the sovereign intervention of a state appears to be particularly important. Yet it should be emphasized that, in the Abaclat and Ambiente Ufficio cases, Argentinian bonds were legally distinct from the Argentinian law, being subjected to laws and fora foreign to Argentina $^{139}$. Therefore, Argentina could not exercise its sovereign powers over these bonds. Any action of Argentina, such as implementing new laws declaring state bankruptcy or refusing debt payment, should be treated as contractual breaches of a rogue debtor declaring non-payment of its contractual obligations. Argentina, rather, used its contractual bargaining power to force a settlement upon its bondholders. Yet, it had no power to unilaterally extricate sovereign bonds from their governing foreign laws. The situation would be different if Argentinian bonds were governed by Argentinian law. In such circumstances, any sovereign decision of Argentina to restructure its foreign debt could prima facie constitute a breach of its treaty obligations.

Nevertheless it appears that, in some circumstances, the mere declaration of non-payment of foreign debts may provide a sufficient basis for investors to initiate treaty claims. Bearing in mind that restructuring processes could effect in arbitral proceedings against states, particular states could simply stop paying their debts without any specific actions having been taken towards investors. These would be intentional state decisions, seeking to avoid liability for a breach of treaty obligations. If deemed to constitute ordinary breaches of contract, such conduct could

138 Abaclat and others $v$. the Argentine Republic, Decision on jurisdiction and admissibility, supra, at para 321-324.

139 G. Abi-Saab, Abaclat and Others v. Argentina, Decision on Jurisdiction and Admissibility, Dissenting Opinion, supra, at para 78. Ambiente Ufficio S.p.A. and others v. the Argentine Republic, Decision on jurisdiction and admissibility, supra, at para 547. 
paradoxically give states more advantages than restructuring efforts. Moreover, a restructuring process can take the form of more or less informal pressure on debt holders to impose settlement conditions upon them, without involving any formal denial of their rights ${ }^{140}$. Therefore, each individual situation should be on its particular facts and merits, bearing in mind that state default is an intentional decision of a state, often within the sphere of imperium and not dominium.

In light of the above, state conduct will provide a basis for treaty claims when it does not constitute an ordinary contractual default but, rather, a sovereign decision of a state calling into question its obligation to pay debts for sovereign policy reasons. In such situations, the state does not merely defer payment but completely denies the obligation to repay investors. It exercises its powers over invested funds, compelling investors to accept settlement conditions imposed unilaterally by the state. Applying such an interpretation, the Argentina exchange offer towards sovereign bondholders and the associated legislation can be treated as a sovereign decision and expression of state power, as stated by the Abaclat and Ambiente Ufficio tribunals ${ }^{141}$.

\section{Conclusion}

The Abaclat and Ambiente Ufficio decisions on jurisdiction create a new legal loophole for sovereign bondholders, allowing them to sue defaulting states directly before international arbitral tribunals. Whilst qualification of security entitlements as investments appears to this write to be an improper conclusion, nothing stands in the way of qualifying sovereign bonds as investments. The tribunals confirmed that both the ICSID Convention and the relevant BIT permitted sovereign bondholders'

140 As emphasized by the Ambiente Ufficio tribunal, the state can influence bonds within its jurisdiction for instance by: "legally forbidding the executive authorities to enter into any settlement of the claims in question or by ordering the domestic judicial authorities, should an 'old' bond come before them, to replace ipso jure the old bonds by the newly issued bond instruments" (Ambiente Ufficio S.p.A. and others v. the Argentine Republic, Decision on jurisdiction and admissibility, supra, at para 547).

141 Abaclat and others v. the Argentine Republic, Decision on jurisdiction and admissibility, supra, at para 325; Ambiente Ufficio S.p.A. and others v. Argentine Republic, Decision on jurisdiction and admissibility, supra, at para 548. See also point 2 above. 
claims, even when a territorial link requirement is contained in the BIT. Moreover, it is possible to differentiate between contractual and sovereign state actions towards sovereign bondholders. Consequently, sovereign bondholders may have direct treaty claims against states which breach their treaty obligations.

These decisions may change the manner in which states approach sovereign debt restructuring and they may influence the way BITs are drafted ${ }^{142}$. In particular, they may inspire states to exclude sovereign debts from the definition of investment, to prohibit mass claims or to clearly confirm the unavailability of arbitration claims concerning sovereign debt restructuring ${ }^{143}$.

Bearing in mind the numerous advantages of ICSID arbitration, especially the relatively uncomplicated enforcement of ICSID awards when compared with judgments of national courts, ICSID arbitration appears to offer an avenue for pursuing sovereign bondholders' claims. It offers those who hold-out additional negotiating tools as they bargain with defaulting states.

Conversely, both decisions considerably undermine states' powers to effectively restructure their sovereign debts. It appears that the effectiveness of collective action clauses ("CACs") in bonds may be undermined by holdouts who oppose majority decisions taken within the scope of $\mathrm{CACs}^{144}$. Holdouts may be able to obtain compensation by way of ICSID proceedings, even though the contractually prescribed majority of bondholders has already accepted the sovereign debt restructuring ${ }^{145}$.

142 J. Beess und Chrostin, Sovereign debt restructuring and mass claims arbitration before the ICSID, the Abaclat case, op. cit., at p. 516.

143 Ibidem.

144 Collective action clauses (CACs) are contractual provisions found in many bonds, allowing the majority of bondholders (in most cases $75 \%$ majority is required) to modify key terms of particular bonds, despite the opposition of the remaining bondholders. As of 1.1.2013, the eurozone states are obliged to include CACs in bonds with a maturity of greater than one year, irrespective of their governing law. See: M. N. Dhonncha, EU publishes mandatory Collective Action Clause for use in eurozone sovereign bonds from 1 January 2013, Linklaters, London 28.5.2012, available at: http://www.linklaters.com/ Publications/EU-publishes-mandatory-Collective-Action-Clause-use-eurozone-sovereignbonds-1January2013/Pages/Index.aspx.

145 M. Waibel, Opening Pandora's box: sovereign bonds in international arbitration, op.cit., at pp. 736-737. 
Even those bondholders who have settled with defaulting states may be permitted to use investment arbitration and complain of discriminatory treatment or a breach of the fair and equitable treatment standard $^{146}$. This relates specifically to bondholders who settled at an earlier phase of the restructuring process and received considerably worse settlement conditions than those bondholders taking part in subsequent settlements. As regards states' exchange offers, the Abaclat and Ambiente Ufficio awards on the merits are still awaiting delivery. They will probably provide an answer to the question concerning the scope of permissible state actions within sovereign debt restructuring processes ${ }^{147}$. However, given the broad formulation of BIT standards of treatment, which seek to protect investors rather than states' regulatory powers, and the common use of umbrella clauses in BITs which transform contractual claims into treaty claims, it may be assumed that states' regulatory powers will be wholly subject to investors' private property rights ${ }^{148}$.

It stems from the above considerations that the Abaclat and Ambiente Ufficio decisions may considerably undermine states' abilities to effectively restructure their sovereign debts during times of financial crisis. The number of sovereign debt disputes before international arbitral tribunals will likely increase and holdouts will be less eager to settle with defaulting states ${ }^{149}$. Investment arbitral tribunals are ill-equipped to settle sovereign debt restructuring disputes. They focus on the proprietary rights of particular claimants rather than on the whole group of state creditors. Therefore, they can present divergent views on the same matters, reach different conclusions and consequently breach the principle of intercreditor equality in the restructuring process.

146 I. Glinavos, Investors v. Greece. The Greek 'Haircut' and Investor Arbitration under BITs, p. 1, at p. 4, available at: http://papers.ssrn.com/sol3/papers.cfm?abstract_id=2021137.

147 However, it should be noted that Argentina has not invoked a state of necessity provision excusing its non-performance of obligation due to the financial crisis. See: Abaclat and others v. the Argentine Republic, Decision on jurisdiction and admissibility, supra, at para 321.

148 R.M. Ziff, The Sovereign Debtor's Prison: Analysis of the Argentine Crisis Arbitrations and the Implications for Investment Treaty Law, op. cit., at pp. 358-365.

149 M. Waibel, Opening Pandora's box: sovereign bonds in international arbitration, op. cit., at p. 758. 
No uniform rules on sovereign debt restructuring have been adopted to date. The creation of a sovereign debt tribunal remains far from reality ${ }^{150}$. Accordingly, the only possible option available for states remains the renegotiation of existing BITs, especially narrowing the scope of the definition of an investment. Until such a change occurs in BITs, arbitral tribunals should more liberally accept the necessity exception invoked by defaulting states. This could permit states to introduce various regulatory measures necessary to address the adverse effects of financial crises, without the fear of sustaining liability for breach of sovereign bondholders' treaty rights.

150 Such a tribunal will add no benefit to creditors enabled to assert their claims before the other - contractual and investment fora. See: I. Hanefeld, Is there a Need for a Sovereign Debt Tribunal, 'Transnational Notes. Reflections on Transnational Litigation and Commercial Law', 8.10.2012, available at: http://blogs.law.nyu.edu/ transnational/2012/10/is-there-a-need-for-a-sovereign-debt-tribunal/. 